\title{
Brain Metastases in Very Young Patients with Lung Cancer Are Still Brain Metastases
}

\author{
Elizabeth M. Gore \\ Department of Radiation Oncology, Medical College of Wisconsin, Milwaukee, WI, USA
}

In this issue of ONKOLOGIE, Nieder and colleagues retrospectively reviewed 149 patients treated with whole brain irradiation for lung cancer with subset evaluation of 9 patients under the age of 40 [1]. Five of the 9 patients had small cell lung cancer. Median survival was 7 months. Median Karnofsky performance score (KPS) was 70. Only one of 8 patients with complete follow-up information died as a direct result of CNS disease. In conclusion, the very young patients did not achieve a better outcome than intermediate age groups. Radiation provided durable CNS control in nearly all patients, while systemic failures remained the leading cause of death.

The small percentage $(6 \%)$ of very young patients in this study is consistent with the age distribution of lung cancer in the general population: less than $5 \%$ of patients with lung cancer are less than 40 years old [2-4]. Due to these small numbers, studies do not focus on prognosis and therapy of this particular age group. Standard therapy is based on treatment of patients with varying histologies, stage of disease and underlying comorbid conditions.

Younger patients differ from older patients in terms of histology, genetic susceptibility, and gender distribution. Younger patients have a lower male/female ratio than older patients [3-5]. Lung cancer risk is higher in young patients with family history of smoking suggesting a genetic predisposition to lung cancer in patients with early onset of disease [5-7]. Contrary to the dominant small cell histology in the current study, younger patients tend to have a higher incidence of adenocarcinoma [3-5, 8]. In addition to differences in gender ratios, genetic predisposition and histological differences, patients $\leq 40$ years may tolerate therapy better and be willing to accept a higher risk of toxicity than patients $\geq 65$. These differences in younger versus older patients with lung cancer support the need to evaluate treatment and outcomes in very young patients separate from older lung cancer patients.

Recursive partitioning analysis (RPA) of RTOG brain metas- tases trials (61\% of patients had lung cancer) identified three prognostic groups [9]. Favorable prognostic factors included KPS $\geq 70$, age $<65$ years, controlled primary tumor, and no extra-cranial metastases. Other studies have validated these results $[10,11]$. RPA classification has also been validated for small cell lung cancer [12]. Although younger age is a favorable prognostic factor, the age cut off for these studies is 65 years. These studies do not specifically address prognostic factors of very young patients. In the current study [1], very young patients with brain metastases did not achieve a better outcome than intermediate age groups.

Whole brain irradiation in the current study was effective in palliating CNS symptoms and preventing death from CNS disease. Unfortunately these patients had uncontrolled extra-cranial disease. Better systemic therapy may improve outcomes but early detection of disease, when it is potentially curable, and prevention of CNS failures is needed to significantly improve survival.

Prophylactic cranial irradiation (PCI) is accepted as part of standard therapy for small cell lung cancer. PCI has been shown to improve survival in patients with limited disease small cell lung cancer by 5,4\% [13]. Additionally PCI has been shown to decrease symptomatic brain failures and improve 1year overall survival in patients with extensive disease SCLC [14].

Prospective randomized studies have shown that PCI decreases and delays CNS failures in patients with non-small cell lung cancer but studies have not been powered to show a survival advantage [15-17]. Further studies are needed clarify the role of PCI in NSCLC, particularly in high-risk patients. Non-small cell lung cancer patients at highest risk for CNS failures include younger patients. Studies have shown that younger age predicts for an increased risk of brain metastases and earlier brain failures in patients with non-small cell lung cancer [18-21].

\begin{tabular}{ll}
\hline KARGER & @ 2008 S. Karger GmbH, Freiburg \\
Fax +497614520714 & Accessible online at: \\
$\begin{array}{l}\text { E-mail Information@Karger.de } \\
\text { www.karger.com }\end{array}$ & www.karger.com/onk \\
&
\end{tabular}

Elizabeth M. Gore, MD

Associate Professor of Radiation Oncology

Medical College of Wisconsin

9200 West Wisconsin Avenue, Milwaukee, WI 53226, USA

Tel. +1 414 805-4465, Fax -4369

E-mail egore@mcw.edu 
Unfortunately, with rare exceptions and regardless of age, histology, and site of primary disease, the prognosis of patients with brain metastases is very poor. Better understanding of the disease process and prognostic factors will help to cus- tomize therapy and ultimately improve outcomes. Smoking is the most important risk factor for lung cancer in the very young. Preventing young people from smoking will have the most significant impact.

\section{References}

1 Nieder C, Thamm R, Astner ST, Molls M: Disease presentation and treatment outcome in very young patients with brain metastases from lung cancer. Onkologie 2008;31:305-308.

2 Roviaro GC, Varoli F, Zannini P, Fascianella A, Pezuoli G: Lung cancer in the young. Chest 1985; 87:456-9.

3 Green LS, Fortoul TI, Ponciano G, Robles, Rivero O: Bronchogenic cancer in patients under 40 years old. The Experience of a Latin American country. Chest 1993;104:1477-81.

4 Jubelirer SJ, Wilson RA: Lung cancer in patients younger that 40 years of age. Cancer 1991;67: $1436-8$.

5 Kreuzer M, Kreienbroch L, Muller KM, Gerken M, Wichmann E: Histologic types of lung carcinoma and age at onset. Cancer 1999;85:1958-65.

6 Schwartz AG, Yang P, Swanson GM: Familial risk of lung cancer among nonsmokers and their relatives. Am J Epidemiol 1996;144:554-62.

7 Ambrosone CB, Rao U, Michalek AM, Cummings $\mathrm{KM}$, Mettlin CJ: Lung cancer histologic types and family history of cancer. Anlaysis of histologic subtypes of 872 patients with primary lunge cancer. Cancer 1993;72:1192-8.

8 Bourke W, Milstein D, Giura R, Donghi M, Luisette M, Rubin AHE, Smith LJ: Lung cancer in young adults. Chest 1992;106:1723-9.

9 Gaspar L, Scott C, Rotman M, Asbell S, Phillips T, Wasserman T, McKenna WG, Byhardt R: Recursive partitioning analysis (RPA) of prognostic factors in three radiation therapy oncology group (RTOG) brain metastases trials. Int J Radiation Oncology Biol Phys 1997;37:745-51.
10 Nieder C, Nestle U, Motaref B, et al.: Prognostic factors in brain metastases: should patients be selected for aggressive treatment according to recursive partitioning analysis (RPA) classes. Int J Radiation Oncology Biol Phys 2000;46:297-302.

11 Agboola O, Benoit B, Cross P, et al.: Prognostic factors derived from recursive partition analysis (RPA) of radiation therapy oncology group (RTOG) brain metastases trials applied to surgically resected and irradiated brain metastatic cases. In J Radiation Oncology Biol Phys 1998;42:155-159.

12 Videtic GMM, Adelstein DJ, Mekhail T, Rice TW, Stevens GHJ, Lee SY, Suh JH: Validation of the RTOG recursive partitioning analysis (RPA) classification for small-cell lung cancer-only brain metastases. Int J Radiation Oncology Biol Phys 2007;67: 240-3.

13 Auperin A, Arriagada R, Pignon JP, Pechoux CL, Gregor A, Stephens RJ, Kristjansen PEG, Johnson GE, Ueoka H, Wagner H, Aisner J: Prophylactic cranial irradiation for patients with small-cell lung cancer in complete remission. N Engl J Med 1999; 341:476-84.

14 Slotman B, Faivre-Finn C, Kramer G, Rankin E, Snee M, Hatton M, Postmus P, Collette L, Musat E, Senan S: Prophylactic cranial irradiation in extensive small-cell lung cancer. N Engl J Med 2007;357: 664-72.

15 Cox JD, Stanley K, Petrovich Z, Paig C, Yesner R: Cranial irradiation in cancer of the lung of all cell types. JAMA 1981;245:469-472.
6 Russell AH, Pajak TE, Selim HM, et al.: Prophylactic cranial irradiation for lung cancer patients at high risk for development of cerebral metastasis: Results of a prospective randomized trial conducted by the Radiation Therapy Oncology Group. Int J Rad Onc Biol Phys 1991;21:637-43.

17 Umsawasdi T, Valdivieso M, Chen TT, et al.: Role of elective brain irradiation during combined chemoradiotherapy for limited disease non-small cell lung cancer. J Neuro-Onc 1984;2:253-9.

18 Carolan H, Sun AY, et al.: Does the incidence and outcome of brain metastases in locally advanced non-small cell lung cancer justify prophylactic cranial irradiation or early detection? Lung Cancer 2005;49:109-115.

19 Ceresoli GL, Reni M, Chiesa G, Carretta A, Schipani S, Passoni P, Bolognesi L, Zannin P, Villa E: Brain metastases in locally advanced nonsmall cell lung carcinoma after multimodality treatment: Risk factors analysis. Cancer 2002;95:605-612.

20 Herbert SH, Curran WJ, Rosenthal SA, Stafford PM, McKenna WG, Hughes EN, Sandler HM: Adverse influence of younger age on outcome in patients with non-smal cell lung carcinoma (NSCLC) treated with radiation therapy (RT) alone. Int J Radiation Oncology Biol Phys 1992;24:37-42.

21 Gaspar LE, Chansky KS, Albain K, Vallieres E, Rusch V, Crowley JJ, Livingston RB, Gandara D: Time from treatment to subsequent diagnosis of brain metastases in stage III non-small-cell lung cancer: a retrospective review by the southwest oncology group. J Clin Oncol 2005;23:2955-61. 